\title{
God Can Wait - New Migrants in Germany Between Early Adaptation and Religious Reorganization
}

\author{
Claudia Diehl* and Matthias Koenig**
}

\begin{abstract}
We analyse migration-related changes in religiosity among new Polish and Turkish migrants in Germany by using data from an international project on Socio-Cultural Integration Processes of New Immigrants in Europe (SCIP). The study confirms that after migration, both groups experience a decrease in religious practices that is more pronounced among Muslim Turks than among Catholic Poles and more pertinent for worship attendance than for prayer. Among new Polish immigrants, religious decrease is greater for individuals with stronger social ties to the secular German mainstream and there are no signs that religious practices are resumed after the disruptive first couple of months. For Turks, however, our study shows that initial religious decrease is followed by a process of religious reorganization, independent of social assimilation. We discuss the role that "bright" symbolic boundaries against Islam may play in explaining these group-specific patterns.
\end{abstract}

\section{INTRODUCTION}

Within the new scholarship on the religiosity of migrants in Western Europe, the major focus for obvious reasons has been upon integration patterns among Muslim immigrants and their children. In addition to qualitative work on individual styles, organizational forms, and political mobilization of Islam (for an early review see Tezcan 2003), there is now an emerging quantitative literature on various aspects of Muslim religiosity in Western Europe (for review see Voas and Fleischmann, 2012). For instance, several studies have found Muslim religiosity to decrease from first to second generation (on the Netherlands see Maliepaard et al., 2010; Phalet et al., 2008; on Belgium see Smits et al., 2010), although others point to greater inter-generational stability (on Germany Diehl and Koenig, 2009; Jacob and Kalter, in this issue). It has also been argued that levels of Muslim religiosity are affected by contextual factors such as public hostility against immigrants (Connor, 2010). In light of widespread perceptions of "bright" religious boundaries against Islam (Zolberg and Woon, 1999; Alba, 2005), scholars have furthermore started to address ethno-religious penalties in education and on the labour market (Connor and Koenig 2013), and to analyse how religiosity is linked with structural and social assimilation across integration contexts. Comparative studies within Europe suggest, for instance, that in contexts with strong institutional closure against Islam, unlike in more accommodative contexts, Muslim religiosity is negatively related with structural assimilation (Fleischmann and Phalet 2012).

*University of Konstanz, Konstanz.

**University of Göttingen \& Max Planck Institute for the Study of Religious and Ethnic Diversity, Göttingen 
However, many questions concerning the link between religion and immigrant integration remain unresolved. Perhaps the most important limitation is that by focusing on Muslim migrants exclusively, the existing literature largely fails to put their religious characteristics into comparative perspective with other religious groups, notably with Christians. The few studies that do analyse integration trajectories across different religious groups in Europe (van Tubergen and Sridottir, 2011; Aleksysnka and Algan, 2010: 27) typically suffer from small subsample sizes and limited measures of religiosity. A further limitation is that due to a lack of longitudinal data, the vast majority of studies fail to trace changing patterns of religiosity and their relation to integration processes, among either first or second generation immigrants, over time. And finally, practically nothing is known about the initial period of immigrant integration. While the impact of the migratory event upon religion has been thoroughly studied in the US (Akresh, 2011; Cadge and Ecklund, 2006; Connor, 2009a; Massey and Higgins, 2010) and in Canada (Connor, 2008; Connor, 2009b), in Western Europe no data existed until recently for understanding the early dynamics of immigrant integration, which may prefigure long-term integration outcomes such as structural and social assimilation.

In this article we aim to contribute to the literature on religion and immigrant integration in Western Europe by presenting unique and novel data from an international survey project on SocioCultural Integration Processes of New Immigrants in Europe (SCIP) which, amongst many other topics, allows studying changes in religiosity in the very early period of immigrant integration. We focus on newly arriving Muslim Turks and Catholic Poles in Germany (for a parallel analysis in the Netherlands see Van Tubergen, 2013). Both groups come from highly religious countries of origin and thus share the experience of entering a receiving country that is dramatically more secularized. However, both groups enter quite distinctive religious fields and encounter different ethnic networks resulting from earlier waves of immigration. Most importantly, Turks face the salient religious boundary against Islam while this is not the case for Poles. Comparing both groups should thus provide further insights into the multifaceted dynamics of changing religiosity in the post-migration period.

We start with theoretical arguments about potential changes in newcomers' religiosity after their arrival (Section 2.). We then provide some background information on Turks and Poles in Germany and formulate more specific expectations on their early religious adaptation (Section 3.). After introducing the German SCIP dataset (Section 4.), we present initial empirical findings, showing that worship attendance as well as prayer, albeit to different degrees, decrease considerably among newly arriving Polish and Turkish migrants in Germany and provide insights into underlying mechanisms of religious adaptation (Section 5.). In sum, we find that beyond an initial and substantial drop in religious participation based on lack of opportunities among both groups, Poles and Turks experience rather distinctive dynamics. While for Poles religious decrease is linked with social assimilation, Turks seem to recapture their religious practice with increasing length of stay, independently of their early integration trajectories in other spheres.

\section{THEORETICAL ARGUMENTS}

Within the North American literature, there is a long-standing debate on the effect which migration has upon religious practices. On the one hand, scholars have argued that the migratory event is a traumatic experience that would be conducive to greater religiosity. Migration has even been regarded as a "theologizing" event in which uprooting is interpreted in religious vocabularies of "exodus", "pilgrimage" and the like (see Smith, 1978: 1173). The mechanism implied in this argument is psychological; experiences of anomia or existential insecurity are regarded as potentially increasing the receptivity to religious belief and meaning systems. Such religious beliefs and identities may ultimately translate into active participation in religious communities to the extent that these provide "refuge, respectability and resources" (Hirschman, 2004). 
On the other hand, despite their prima facie plausibility, these arguments have received hardly any support in recent empirical research. In fact, quantitative studies among new immigrants in the US and Canada have shown worship attendance and other indicators of religiosity to decrease and not to increase between pre- and post-migration period (Cadge and Ecklund, 2006; Connor, 2008, 2009a, 2009a; Massey and Higgins, 2011; for overviews see Mol, 1979: 33; Breton, 2012). While it may be true that (some) pioneer migrants in American history were disproportionately involved in religious practices, notably by establishing "ethnic churches" (see Alba et al. 2009), later cohorts of migrants seem to experience different religious dynamics.

But if newly arriving immigrants do indeed experience an overall disruption in religiosity, this raises a number of additional questions. Are there between and within group differences in the extent to which religiosity decreases after the migratory event - and what accounts for these differences? And does the disruption in religiosity constitute a temporary deviation from a habitual pattern of religious practice, or is it the beginning of a long-term assimilation to the mainstream of the receiving society? In the following we discuss these questions by building upon theoretical insights from sociology of religion and migration studies. We formulate three sets of arguments on new migrants' religiosity that address the highly dynamic initial phase of integration upfront.

The first argument essentially focuses on opportunities for religious participation. It is not hard to imagine why the migratory event may be rather disruptive for religious practices. In newcomers' short-term calculus, participation in religious activities competes with secular options (on religioussecular competition see Stolz, 2009), such as finding a home and a job, learning a new language and establishing new social networks. In addition, new immigrants may lack not only time but also infrastructural opportunities for religious involvement. Churches, mosques, or other sites of religious participation may not be readily (known to be) available, especially for members of religious minorities. This implies that members of religious minorities should experience even more of an initial decrease than members of religious majorities, as findings on religious participation among newcomers of non-Catholic and Catholic background in Quebec suggest (see Connor 2008). ${ }^{1}$

The second set of arguments starts from premises of assimilation theories and regards the early disruption of newcomers' religiosity as the first episode in the long story of migrants' acculturation, social network dynamics and structural mobility. ${ }^{2}$ For instance in the US, notwithstanding an initial disruption of religiosity, immigrants quickly start adapting to the vital religious field characteristic of North America by conversion, denominational switching, or increased worship attendance (Akresh, 2011). In Western Europe, by contrast, where societies have become much more thoroughly secularized since the 1960s, migrants would be expected to become less religious as they adapt to the secular mainstream; the initial disruption would thus be regarded as an early phase in newcomers' long-term religious adaptation.

This line of argument posits a number of individual-level mechanisms that link religious change to assimilation in other spheres. As a starting point, immigrants' behaviour is modelled as investment in either ethnic or receiving country options (see e.g. Esser, 2006; see also Alba and Nee, 2003). As long as newly arriving immigrants regard their stay in the receiving country as temporary, they have strong incentives for investing in the maintenance of ethnic social ties and cultural resources that may be relevant for their eventual return. Such incentives weaken, however, as receiving country options - learning the language, achieving educational degrees, establishing a career, making friends - become more attractive. Maintaining religious practices in this perspective is typically regarded as ethnic retention and, hence, as closely linked with ethnic social ties more generally. This perspective builds upon Breton (1964) whose original analysis of ethnic institutional completeness found religious organizations to be of crucial importance for the maintenance of ethnic networks (see also Hagan and Ebaugh, 2002; Levitt, 2003). In sum, religious stability among newcomers is argued to be intricately linked with ethnic orientations, while social and structural assimilation would be conducive to religious decrease. 
Assimilation theory furthermore predicts group differences with respect to the maintenance or decrease of ethnic orientations. For instance, Esser (2006) highlights group size, institutional completeness, and ethnic boundaries as crucial group properties that impinge upon individuals' investment strategies. Newcomers belonging to an immigrant group that faces "bright", that is socially and structurally consequential ethnic boundaries (Alba, 2005) confront costs when maintaining ethnic ties. By implication, for new immigrants from such backgrounds the maintenance of religious practices should be inversely related to social and structural assimilation. By contrast, religious decrease might be less dramatic among immigrants who do not face salient boundaries. For them, "bicultural" options, i.e. orientations towards both the ethnic group and the receiving context (Berry, 1997), may be more feasible thus moderating the (group-specific) link between structural and social assimilation and religious decrease.

Assimilation theory faces a number of problems, however. Above all, religiosity need not necessarily amount to an ethnic investment strategy, as the above arguments implies. Rather, while religiosity does sometimes come along with the maintenance of ethnic identity, religious practices often follow distinctive logics of their own (see e.g. Green, 2002; Mitchell, 2006). Most importantly, empirical evidence suggests that among Muslim migrants in Europe religiosity is relatively stable in segregated as well as mixed neighbourhood contexts (Bisin et al., 2008) and across immigrant generations (Diehl and Koenig, 2009; Jacob and Kalter, in this issue). One could interpret such findings as indicating a greater resilience of cultural practices that are strongly linked to values and identities which have in fact been argued to change more slowly than social networks and structural positions (see e.g. Phalet and Schönpflug, 2001).

Given these considerations, we suggest exploring a third line of argumentation which puts religious boundary dynamics at centre stage. New immigrants facing a "bright" religious boundary such as Muslims in Europe might be expected to maintain their religious practices since religion may constitute a buffer against experiences of discrimination and exclusion. For members of such religious minorities, the migratory event amounts to a "critical transition" that may actually strengthen the salience of hitherto taken-for-granted identity categories (Hardin, 2001), including notably their religious identity. According to this line of argumentation, one would assume that previous levels of religiosity should be recaptured - if not surmounted - after the initial period of disruption. Crucially, such religious reorganization would be expected even notwithstanding early individual assimilation in other social spheres. Put differently, a decoupling of religious from social/structural assimilation seems thus to be more, not less likely for migrant groups facing bright religious boundaries as compared to those not facing such boundaries.

\section{POLES AND TURKS IN GERMANY}

The above mentioned theoretical arguments have so far only been analysed with immigrant survey data from the US and Canada, a context known for its vital, pluralistic religious field and its rather blurred religious boundaries. Western Europe has experienced far more pronounced processes of secularisation and symbolic boundary configurations include "bright" religious markers vis-à-vis Islam (Zolberg and Woon, 1999; Foner and Alba, 2008; Connor and Koenig, 2013). The Western European context thus lends itself to exploring some of the above theoretical arguments in comparative perspective. In this article, we focus on Muslim Turks and Catholic Poles who have newly arrived in Germany. In the following, we provide some background information on these two groups, in order to spell out hypotheses derived from the above theoretical arguments.

Contemporary newcomers from Turkey or Poland enter into rather distinctive trajectories of Germany's post-war history of immigration. There are now about 2.8 million German inhabitants with Turkish migration backgrounds. The pioneer migrants were predominantly male low skill 
labour migrants who came to fill the German economy's labour demand in the 1960s and 1970s. After the recruitment stop in 1973, family members came along and settled permanently in the Federal Republic. Notwithstanding declining levels of immigration, family reunion is still the major migration motive among Turks (Migrationsbericht, 2008: 206). By contrast, while large numbers of Polish speakers had migrated from the eastern Prussian provinces of pre-World War I Germany to the industrial centres in the West, today's 640.000 or so persons with Polish migration backgrounds have mainly come during the post-communist period - either as Aussiedler or as workers or students (Migrationsbericht, 2008: 37-38). Since Poland's accession to the European Union (2004) Poles have received new rights to free movement within the wider European labour market, even though Germany maintained legal barriers to labour migration from Poland until May 2011.

Newcomers arriving from Turkey, a predominantly Muslim country, or coming from overwhelmingly Catholic Poland experience a similar transition from a rather religious to a thoroughly secularized society in Germany. In fact, both Turkey and Poland are among the most highly religious countries in Europe by almost any indicator. Recent ISSP data (2008), for instance, show that more than three quarters of the Turkish and Polish population, respectively, see themselves as somewhat, very or extremely religious; and figures of monthly or more worship attendance are around 50 per cent for both groups. In both countries, religion has become increasingly salient in the political arena, with religious protest movements challenging authoritarian Kemalism and Stalinist socialism and with nationalist movements drawing strongly on Islamic and Catholic traditions, respectively (Yavuz, 2003; Zubrzycki, 2006). For both groups of newcomers, there are thus strong reasons to expect that migration to Europe will prompt considerable changes in religious identities, beliefs, and practices. However, both groups also differ considerably with respect to the factors highlighted in the three lines of theoretical argumentation.

First, newly arriving Turks and Poles enter very differently structured religious sub-fields in Germany. Given the quasi majority status of Catholicism in bi-confessional Germany, Poles should find a sufficiently developed religious opportunity structure; drops in religious participation induced by lack of actual or perceived religious "supply" should thus be less pronounced. Among Turks, there now exists a thriving religious field with strong competition between different strands of Islam including mosque associations sponsored by Turkey's Office for Religious Affairs (Diyanet) and others linked with the varieties of modern Islamic movements (e.g. Milli Görüs, Gülen Movement, Süleymanci). However, despite German governmental initiatives to engage in dialogue with the competing Muslim umbrella organizations (Laurence, 2012; Schiffauer, 2009), difficulties in receiving zoning permits for mosque buildings, let alone equal recognition of religious communities as corporations of public law, still exist. Religious supply thus continues to be less easily available for Muslim Turks than for immigrants affiliated with the well-funded and institutionalized Catholic Church. We thus expect that while both groups should experience a disruption of religious participation and, if to lesser degree, of private religiosity, these drops should be more pronounced among Turks than among Poles.

The second line of argumentation derived from assimilation theory generally predicts religious decrease among newcomers who are determined to stay, build strong ties with majority members, and are structurally integrated into the receiving society. By contrast, religiosity should remain more stable among newcomers committed to return to their country, living in segregated neighbourhoods, and having stronger social and economic ties to the country of origin. While these links should generally hold for Poles and Turks alike, their strength can be expected to vary, since Poles and Turks confront different situations in terms of their ethnic group's size, ethnic institutional completeness, and strength of ethnic boundaries. Given their numbers, newly arriving Muslim Turks enter institutionally more complete ethnic communities than Poles. Moreover, they encounter social distances on behalf of natives and experience discrimination more often than non-Muslim immigrants (Hans, 2010). Hence, assimilation theory would predict that among Turks in Germany, early structural and social assimilation leads to a more pronounced religious decrease; maintaining 
strong Muslim religiosity would simply impose unfeasible costs given the public stigmatization of Islam. For Poles, by contrast, integration should be much more compatible with religious maintenance; while vibrant Catholic religiosity may have become rare among young Germans, one could hardly argue that such religiosity leads to stigmatisation.

According to the third line of argumentation, the brightness of the religious boundary against Islam can be regarded as condition for the maintenance of religious habits independently of early assimilation in other spheres. If relevant at all, early ties with majority members and participation in the German labour market should come along with an adaptation to the German secular mainstream only for Poles. Muslim Turks, by contrast, do not have the option of becoming "just a little less religious". One would thus expect that "bright" symbolic boundaries against Islam foster religious resilience even if pragmatically motivated assimilation in other spheres of lives does occur. Accordingly, Turks who have already stayed longer and will have had the chance to learn more about available mosques recapture their previous levels of religious participation. For them, the initial disruption would thus be precisely that: a disruption which does not preclude religious re-organization while for Poles it might in fact constitute the beginning of a long-term religious assimilation process.

\section{DATA AND METHODS}

To test the theoretical arguments among Poles and Turks in Germany, we draw on data from a unique dataset produced in the international survey project on Socio-cultural Integration Processes among New Immigrants in Europe (SCIP). ${ }^{3}$ The SCIP project is a two-wave-panel study of selected migrant groups in which about 7.000 migrants aged between 18 and 60 are surveyed in four European destination countries - Germany, Netherlands, United Kingdom, and Ireland. In this article, we draw upon data from the first survey wave in Germany. CAPI-interviews in Polish and Turkish were conducted with individuals who have been staying in Germany up to 1.5 years in 2010/2011. Initially, a random sample was drawn from population registers in five large cities. Ultimately, 2.697 face-to-face interviews were conducted in the first wave. Since we are interested in the religiosity of Muslim Turks and Catholic Poles, we limit our analysis to those who declare some religious affiliations (1.343 Poles and 1.028 Turks).

The questionnaire includes a number of items pertaining to religiosity, including worship attendance, prayer, fasting, self-declared religiosity, and identification with a broader religious community, e.g. Christianity or the Islamic Ummah. Moreover, there is information on the ethnic composition of religious communities among those who participate regularly, on assistance received by religious organizations, and on experiences of religious discrimination. We draw on this information wherever it helps interpreting the results of our analysis.

Our main analytical interest, however, is in changes in religiosity after the migratory event. Thus, we rely on those religious items (worship attendance; prayer) that respondents were also asked about retrospectively for the pre-migration period. ${ }^{4}$ In our modelling strategy we draw upon existing studies from the US and Canada that aim to predict post-migration religious practice by various independent variables, including pre-migration religious practice (Akresh, 2010: 654; Massey and Higgins, 2011: 1385). Such an approach assumes that outcome variables such as worship attendance and prayer are to a large degree determined by pre-migration religious practice, and it aims at explaining remaining variance by additional independent variables (for a different modelling approach see Connor, 2008: 252; 2009: 793). In our analysis we follow this basic modelling approach, focusing on those independent variables that capture our major theoretical arguments.

We start with a baseline model that, in addition to pre-migration worship attendance or prayer, includes socio-demographic variables of sex, age, education, and rural background. These factors are generally known to affect religious practice, and in separate analyses we found that they do in 
fact have strong relevance for the two groups' overall religiosity. ${ }^{5}$ The baseline model furthermore includes length of stay (in months) to explore the dynamics of religious change during the first months in Germany. The model allows testing expectations about group-specific rates of decrease among Poles and Turks derived from the first argument about religious opportunities. ${ }^{6}$

To test the second argument developed from the assimilation literature, we start with a variable on respondents' migration situation. Migrants planning to stay in Germany, we assume, will develop stronger orientations to the receiving society than those planning to return, to come and go, or to move to a third country. To capture structural integration, we include a variable on newcomers' main activity, assuming that having a job or studying at a university provides exposure to major spheres of the receiving society. Social assimilation can be measured by ties to people from the receiving context. Given the recent arrival of the migrants upon whom we focus, we use information on the living situation as indicating the strongest possible social ties. Finally, we include (subjectively perceived) ethnic composition of the neighbourhood as an indicator for migrants' early spatial assimilation. We assume that those living in highly segregated neighbourhoods will more readily develop ethnic orientations and, not least, would have easier access to (information on) Turkish mosques or ethnic Polish churches.

We start out with modelling post-migration worship attendance and prayer as dependent on premigration religiosity, socio-demographic characteristics, opportunities, and structural as well as social assimilation for Turks and Poles separately. We finally display a full model including countries of origin as an independent variable, in order to analyse whether differences in religious maintenance between both groups remain stable after controlling for group differences in early integration patterns.

\section{FINDINGS}

Descriptive information on new immigrants from Poland and Turkey in Germany (see Table 1) show that both new immigrant groups share a number of characteristics. They have an average duration of stay of in the country of about eight months, they are rather young, they typically come from urban or suburban background (especially for Turks), and they are relatively well-educated. However, slightly less than half of the Turks plan to stay in Germany, while this is true for only a quarter of the Poles. At the same time, 65 per cent Poles report working as their main activity, while only 22 per cent Turks do so.

Turning to religious practices as our main outcome variable, we first of all find that Poles and Turks display relatively high levels of religiosity even though both groups are somewhat less religious than comparable age groups in Poland and Turkey: While in the ISSP more than over 70 per cent of Poles and over 80 per cent of Turks in the age group between 20 and 40 describe themselves as somewhat, very or extremely religious, self-rated religiosity, among recent newcomers from both countries the figures are at 66.8 per cent and 53.9 per cent, respectively (not displayed in the Table). Still, the means of worship attendance and prayer (Table 1) are clearly above the average of the German population.

What the means of both religious variables also show, however, is that religious practices decrease considerably for both groups, with worship attendance decreasing much more strongly than regular prayer. This finding confirms recent research results from the US and Canada according to which migration is rather disruptive for migrants' religious practices. The differential decrease of worship attendance and prayer furthermore lends some initial support to the opportunity argument which predicts stronger decrease for institutionalized practices that require access to religious infrastructure.

To describe the patterns of decrease in greater detail, we display a bar chart indicating all possible combinations of pre- and post-migration religious participation that seems to be more relevant for the study of early integration patterns than praying (see Figure 1). To start with religious 
TABLE 1

DISTRIBUTION OF MODEL VARIABLES, POLISH CATHOLICS AND TURKISH MUSLIMS (MEANS)

\begin{tabular}{|c|c|c|}
\hline & Poles & Turks \\
\hline \multicolumn{3}{|l|}{ Dependent variables } \\
\hline Religious participation in Germany $(1=$ never; $7=$ weekly $)$ & 3.40 & 2.47 \\
\hline $\begin{array}{l}\text { Religious practice in Germany: praying ( } 1=\text { never; } 6=\text { every day/several times a day) } \\
\text { Independent variables }\end{array}$ & 3.50 & 2.68 \\
\hline Religious participation in Poland/Turkey $(1=$ never; $7=$ weekly $)$ & 4.75 & 4.01 \\
\hline $\begin{array}{l}\text { Religious practice in Poland/Turkey: praying ( } 1=\text { never; } 6=\text { every } \\
\text { day/several times a day) }\end{array}$ & 3.79 & 3.19 \\
\hline Female & .45 & .49 \\
\hline Age & 33 & 28 \\
\hline Education: primary & .06 & .18 \\
\hline secondary & .71 & .46 \\
\hline tertiary & .22 & .33 \\
\hline Background in Poland/Turkey ( $1=$ urban, $5=$ country house) & 2.58 & 1.79 \\
\hline Share Poles/Turks members neighborhood ( $1=$ (almost)none; $5=$ (almost)all) & 2,04 & 2,41 \\
\hline Months since immigration & 8,62 & 7,37 \\
\hline Migration situation: stay in Germany & .23 & .42 \\
\hline move back and forth & .23 & .20 \\
\hline return to Poland/Turkey & .40 & .29 \\
\hline move to third country & .05 & .04 \\
\hline Main activity: working & .65 & .22 \\
\hline in full time education & .16 & .27 \\
\hline unemployed & .08 & .31 \\
\hline looking after home/parental leave & .08 & .13 \\
\hline else (retired, sick, disabled, missing) & .02 & .07 \\
\hline Lives: alone & .20 & .15 \\
\hline only with Poles/Turks & .34 & .32 \\
\hline only with Germans & .10 & .34 \\
\hline with Poles/Turks and with Germans & .36 & .20 \\
\hline
\end{tabular}

Source: SCIP Project, own calculations.

participation in the pre-migration period, the chart underlines that Catholic Poles were considerably more strongly involved in the Church than Muslim Turks are involved in mosque life, probably due to well-known gender differences in mosque participation among Muslims. At the same time, religious practice seemed more polarized among Turks than among Poles. On the one hand, more than a quarter of Turks never attended mosque, while only slightly above five per cent of Poles abstained from worship attendance entirely. On the other hand, more than ten per cent of Turks, but less than five per cent of Poles, say they attended worship daily.

Of crucial interest, however, are patterns of change in religious participation from pre- to postmigration period. As Figure 1 shows, an increase in religious participation can be observed among only very small fractions of either Poles or Turks. Unsurprisingly, stability is strongest among those who never attended church or mosque anyway. Of greatest interest are the specific patterns of decrease among both groups. Regardless of the pre-migration level of religious participation, a substantial number of respondents indicate they would never attend worship in Germany. For instance, of those Turks who indicate weekly mosque attendance before having migrated, about a third never go to mosque in Germany. The most obvious reason for such extreme drops in religious practice would be lack of (knowledge about) religious infrastructure necessary to pursue one's religious habits. Thus, the opportunities argument seems to receive some initial support from our empirical data. In analyses not shown here, we find that among those Poles and Turks who do participate regularly in worship, most attend ethnically highly homogenous churches or mosques. Preferences for ethnic religious institutions may underline that both groups confront a less developed religious infrastructure 
FIGURE 1

RELIGIOUS PARTICIPATION OF POLISH CATHOLICS (P) AND TURKISH MUSLIMS (T) IN GERMANY BY RELIGIOUS PARTICIPATION IN COUNTRY OF ORIGIN

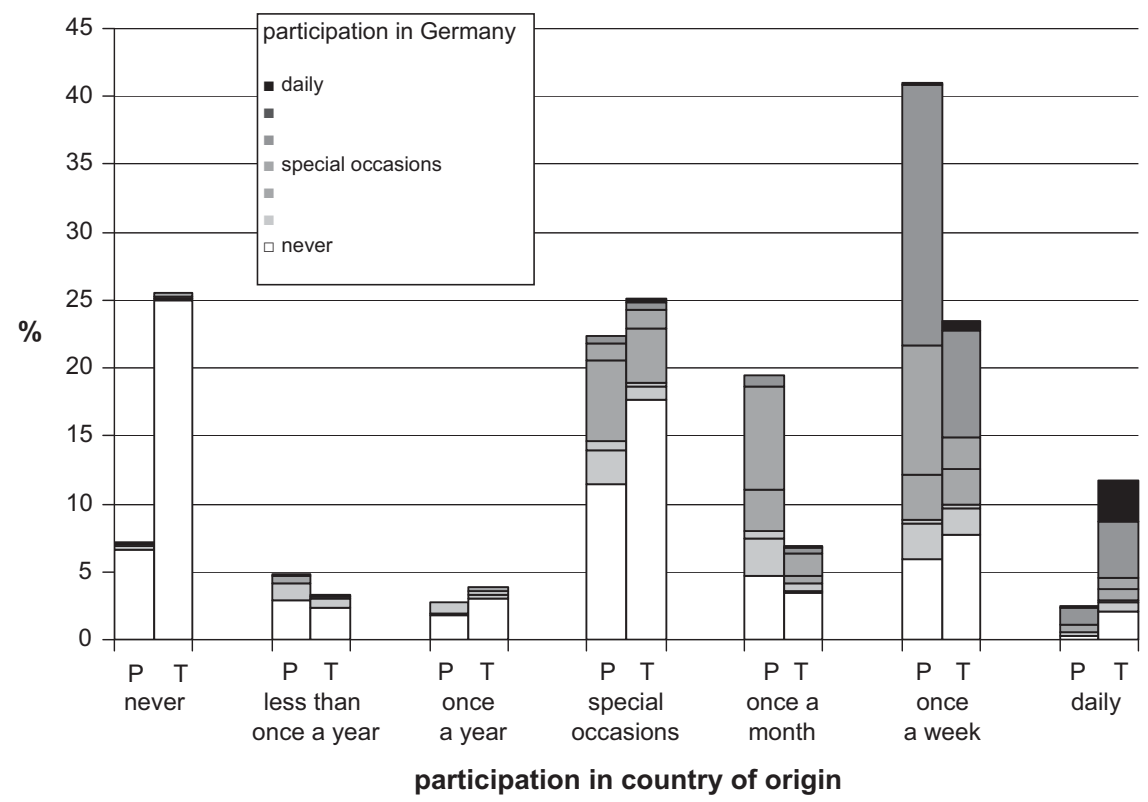

than in their homeland, however, Poles can still be expected to find more opportunities for religious participation given the majority status of Catholicism in certain German cities - and indeed they seem to experience a slightly less pronounced decrease in their worship attendance than Turks.

To test the various theoretical arguments more comprehensively, we move to multivariate analyses starting with religious participation as a dependent variable. The baseline model (Table 3, model I for both groups) shows that pre-migration religiosity is a strong predictor of religious participation after the migratory event for both groups, although the effects are stronger for Poles $(b=.75)$ than for Turks $(b=.53)$. Apart from that, patterns of religious participation differ markedly between the two groups. Among Turks, being female has a strong negative effect on post migration religious participation while for Poles it seems to be elderly women who retain high levels of religious participation. Religious participation in Germany is not associated with new migrants' level of education. Interestingly, length of stay has a positive effect upon stability in religious attendance $(b=.04)$ only for Turks but not for Poles. For Turks, a greater initial decrease seems to be followed by religious reorganization, while for Poles there is no evidence that they resume to their high levels of pre-migration religious participation. Finally, model I of the full sample confirms that Turks experience a substantially stronger religious decrease than Poles even if differences in both groups' socio-demographic composition are held constant (see the negative coefficient for being Turkish).

To test the arguments about assimilation and religious reorganization, respectively, we include the variables measuring social and structural assimilation (see model II). The socio-demographic effects described above remain stable in the full models and the results differ rather strongly between the two groups. For Poles, it seems that while religious participation is unrelated to their settlement intentions, social assimilation has effects as predicted by assimilation theory. Compared with those living together exclusively with Germans, all other living situations come with stronger religious participation.

Results are rather different for Turkish newcomers. True, those committed to return to Turkey display greater stability in their religious participation than those who plan to stay in Germany 
TABLE 2

WHICH FACTORS INFLUENCE STABILITY IN RELIGIOUS PARTICIPATION? POLISH CATHOLICS AND TURKISH MUSLIMS (LINEAR REGRESSION, UNSTANDARDIZED COEFFICIENTS)

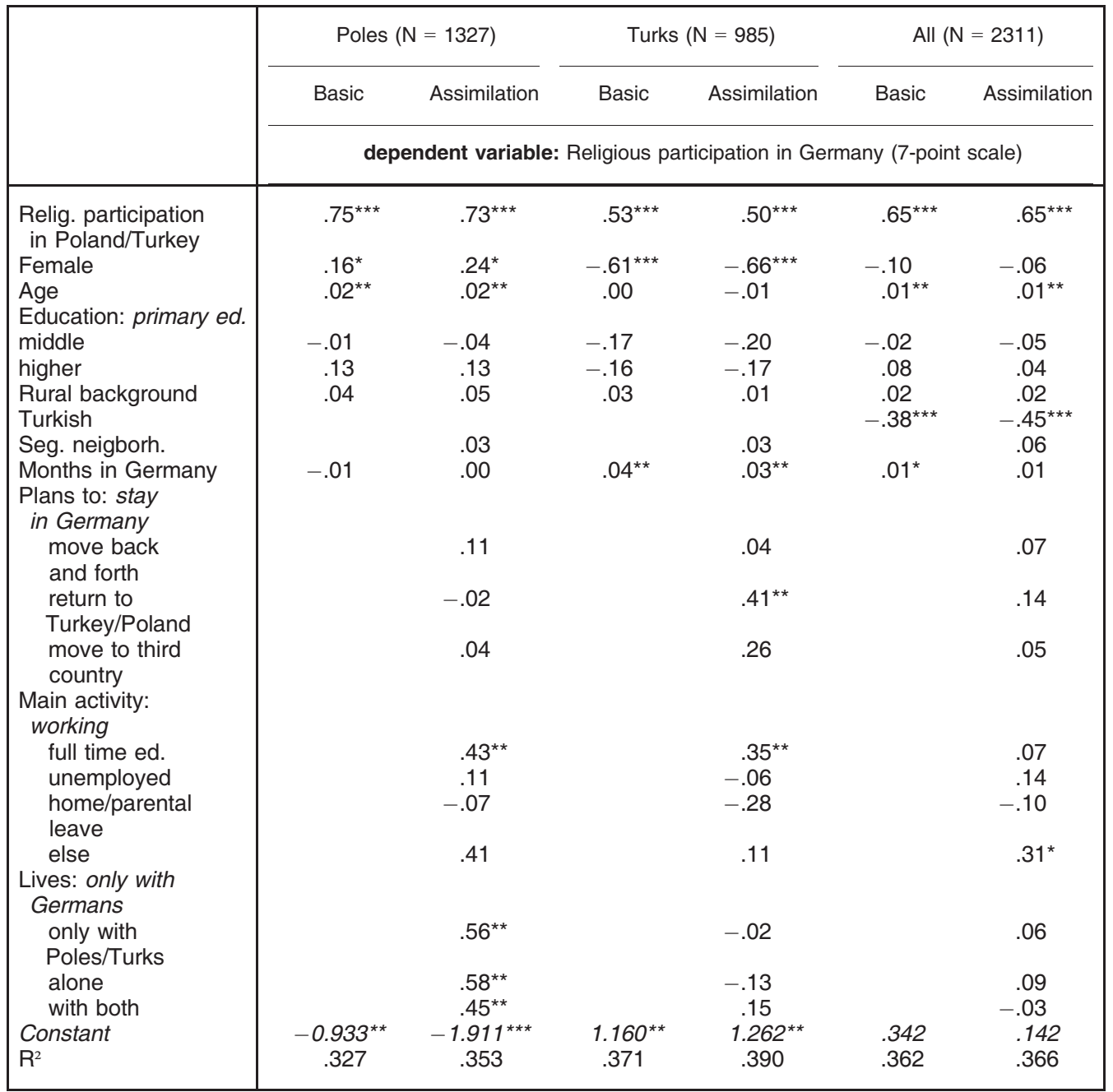

Notes: $* \mathrm{p}<.10 * * \mathrm{p}<.05 * * * \mathrm{p}<.001$; all full models control for city of interview.

$(\mathrm{b}=.41)$. But the living situation, i.e. cohabiting with natives or with Turkish migrants (or ethnic segregation in the neighbourhood) does not have any statistically significant effect upon religious participation. ${ }^{7}$ And above all, the effect of length of stay remains rather stable after the inclusion of assimilation variables. For Turks, in sum, the empirical evidence points into the direction of our third argument about religious reorganization occurring independently of social assimilation. Unlike Catholic Poles - who can find a religious infrastructure in Germany - Turks experience not only greater religious decrease after immigration but also show a pattern of resuming religious activities over time - even after controlling for structural and social assimilation.

While the findings on both groups' social assimilation are straightforward, structural assimilation, e.g. having a job versus being unemployed, does not seem to play an important role for either group. Among both groups, however, being in full-time education, which typically means studying 
TABLE 3

WHICH FACTORS INFLUENCE STABILITY IN PRAYING? POLISH CATHOLICS AND TURKISH MUSLIMS (LINEAR REGRESSION, UNSTANDARDIZED COEFFICIENTS)

\begin{tabular}{|c|c|c|c|c|c|c|}
\hline & \multicolumn{2}{|c|}{ Poles $(N=1276)$} & \multicolumn{2}{|c|}{ Turks $(\mathrm{N}=966)$} & \multicolumn{2}{|c|}{ All $(N=2242)$} \\
\hline & Basic & Assimilation & Basic & Assimilation & Basic & Assimilation \\
\hline & \multicolumn{6}{|c|}{ dependent variable: Praying in Germany (6-point scale) } \\
\hline $\begin{array}{l}\text { Praying in } \\
\text { Poland/Turkey }\end{array}$ & $.90^{\star \star *}$ & $.90^{\star \star \star}$ & $.77^{\star \star \star}$ & $.76^{\star \star \star}$ & $.84^{\star \star \star}$ & $.84^{\star \star \star}$ \\
\hline Female & $.27^{\star \star *}$ & $.34^{* \star *}$ & $.16^{*}$ & .09 & $.23^{* * *}$ & $.25^{\star \star *}$ \\
\hline Age & .00 & .00 & .01 & .00 & $.01^{*}$ & .00 \\
\hline Education: primary ed. & & & & & & \\
\hline middle & -.03 & -.01 & -.14 & -.13 & -.07 & -.06 \\
\hline higher & .06 & .09 & -.15 & -.16 & -.01 & .00 \\
\hline Rural background & .04 & .04 & -.02 & -.03 & .01 & .00 \\
\hline Turkish & & se* & & 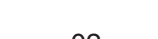 & $-.32^{\star \star \star}$ & $-.29^{\star \star \star}$ \\
\hline Seg. neigborh. & & $-.06^{\star}$ & & .02 & & -.01 \\
\hline Months in Germany & .00 & -.01 & $.02^{\star \star}$ & $.02^{\star *}$ & .01 & .01 \\
\hline $\begin{array}{l}\text { Plans to: stay in } \\
\text { Germany }\end{array}$ & & & & & & \\
\hline move back and forth & & .08 & & .05 & & .08 \\
\hline $\begin{array}{l}\text { return to } \\
\text { Poland/Turkey }\end{array}$ & & .06 & & $.23^{\star \star}$ & & $.11^{*}$ \\
\hline move to third country & & .16 & & .24 & & $.20^{*}$ \\
\hline Main activity: working & & & & & & \\
\hline full time ed. & & $-.15^{\star}$ & & -.15 & & -.12 \\
\hline unemployed & & .11 & & .06 & & .06 \\
\hline home/parental leave & & -.15 & & -.01 & & -.07 \\
\hline else & & $.36^{\star *}$ & & .15 & & .17 \\
\hline Lives: only with & & & & & & \\
\hline Germans & & & & & & \\
\hline $\begin{array}{l}\text { only with } \\
\text { Poles/Turks }\end{array}$ & & $.31^{* *}$ & & .10 & & $.15^{\star \star}$ \\
\hline alone & & $.29^{* *}$ & & .13 & & $.18^{* \star}$ \\
\hline with both & & $.32^{\star *}$ & & $.32^{\star *}$ & & $.22^{\star *}$ \\
\hline Constant & $-.442^{\star *}$ & $-.587^{* *}$ & -.168 & -.246 & .164 & .001 \\
\hline $\mathrm{R}^{2}$ & .741 & .745 & .619 & .620 & .691 & .693 \\
\hline
\end{tabular}

Notes: $* p<.10 * * p<.05 * * * p<.001$; all full models control for city of interview.

at a university, seems to accompany greater religious stability. After all, university students may find relatively easy access to Catholic or Muslim student groups which, in turn, provide (knowledge about) opportunities for religious involvement.

Turning to prayer as dependent variable confirms a number of the insights gained from the analysis of worship attendance. First of all, the opportunities argument receives additional support by the fact the decrease in private prayer is far less pronounced than the decrease in worship attendance. Pre-migration prayer for both groups has stronger effects on post-migration prayer than pre-migration attendance for current worship attendance, although the effects are again weaker among Turks than among Poles. It is also interesting that Turkish women tend to experience greater stability in prayer than in worship attendance, which might point to gender-specific dimensions of religious opportunity structures. Finally, length of stay again has an effect on religious practice as measured by prayer, among Turks, but not among Poles.

The full models also confirm grosso modo the findings discussed in greater detail for religious worship attendance. Among Poles, social assimilation, i.e. living together with Germans only comes 
with less religious stability. Among Turks, plans of returning to Turkey tend to be linked with religious stability, while social assimilation does again not have any effect. The effects of length of stay remain unchanged for this group, thus supporting the idea of an early process of religious re-organization among newcomers from Turkey. Again, structural assimilation is unrelated to both group's levels of religiosity. Moreover, those in full-time education are not more likely to engage in regular prayer, which confirms our interpretation above that studying at German universities provides better access to opportunities for socially embedded religious activities.

\section{DISCUSSION AND CONCLUSIONS}

In this article, we have analysed patterns of religiosity after the migratory event among recent immigrants into Germany from Poland and Turkey. This is one of the first studies to address questions of religious change after the migratory event in Western Europe.

We find mixed support for some of the major arguments advanced in the existing literature. Above all, the study confirms that far from constituting a "theologizing" experience new immigrants experience a decrease in religious practices, as previous research in North America has found for a similar finding on recent immigrants in the Netherlands (see Van Tubergen, 2013). In line with the argument that initial drops in religious practice are partly due to lacking access to religious opportunities, we found religious decrease to be greater among Muslim Turks than among Catholic Poles and to be more pronounced for worship attendance than for prayer. The crucial question, however, is whether such opportunity-based initial drops in religious practice constitute the beginning of a long-term process of religious adaptation linked with structural and social assimilation, or whether they are followed by a process of religious re-organization, independently from assimilation in other social spheres. For immigrants coming from Poland, we found that, as suggested by assimilation theory, individuals with pronounced social assimilation experience stronger religious decrease than those having weaker ties to the secular German mainstream. Moreover, there are no signs that religious practices are being resumed after the rather disruptive first couple of months. Turks, however, seem to resume their various religious activities. Moreover, this process of religious reorganization - which classical assimilation theory leaves rather underspecified - is relatively independent from social and structural assimilation. It may be assumed that "bright" symbolic boundaries against Islam in Germany play an important role in this process; they render gradual acculturation difficult if not impossible for this group and thus contribute to greater religious stability as previous studies have also found (see Diehl and Koenig, 2009).

Evidently, our analysis faces a number of limitations. Compared to some of the more qualitative literature, our data are unable to capture which kind of religious communities newcomers enter. Moreover, measuring religious change by relying on retrospective information about worship attendance and prayer is certainly less reliable than measuring these changes prospectively. Structural and social assimilation is also measured as a time-independent variable, thus missing the highly dynamic changes that individuals experience in the first years of their stay. We have to await the second wave of the SCIP project to address these limitations and to thus gain more robust results about the early dynamics of religious change.

In spite of these limitations, we are confident that our analyses contribute to the existing literature by offering a first insight into the early dynamics of religious change in the Western European context, in group-comparative perspective. Our empirical results suggest that classical assimilation theories need to be complemented by theoretical arguments that capture the dynamics of religious reorganization and reproduction among new immigrants facing bright religious boundaries. If such religious reorganization indeed turned out to be a stable pattern among non-Christian immigrants in Western Europe, this would have far-reaching implications. Our first findings on religiosity among newcomers to Germany in fact lend some support to the view, expressed by various authors (Bramadat and Koenig, 2009), that publicly visible religious diversity may well remain a permanent feature of modern immigrant societies. 


\section{ACKNOWLEDGEMENTS}

Both authors have contributed equally to this article. We acknowledge financial support from NORFACE research programme on Migration in Europe - Social, Economic, Cultural and Policy Dynamics. Earlier versions of the article were presented at the Conference of the European Population Studies Association (EPSA) in Stockholm and at the German Sociological Association Bi-Annual Congress in Bochum; we are grateful to Phillip Connor and the anonymous referees for helpful comments and advice.

\section{NOTES}

1. Building on the supply-side theory in sociology of religion, one might even push the argument further so as to say that a de-regulated religious economy, religious diversity and inter-religious competition stimulate religious vitality (see Connor 2009).

2. Similar to most of the recent literature, we see "assimilation" as occurring under contingent contextual conditions, and in various dimensions whose interrelation is subject to empirical study; see Brubaker 2001.

3. The SCIP project is funded by the NORFACE Research Programme on Migration and is coordinated by Claudia Diehl at the University of Konstanz.

4. Retrospective questions were also asked about religious fasting and, among Turkish women, about wearing headscarves. We do not analyse these items since some respondents did not yet have any occasion (Ramadan or Lent) for fasting and since we are interested in group comparisons,

5. We measured Turks' and Poles' overall religiosity by creating an additive index including all religious items included in the SCIP questionnaire (Cronbach's alpha $=.746$ ) and regressed it on core socio-demographic variables. As one would expect, religiosity is positively correlated with age, being female, and coming from rural background for Poles. Among the Turks, it is the young and the male who tend to be more religious.

6. We also include city of interview (not displayed in the models) to account for potential selectivity of respondents and unobserved contextual factors.

7. Due to data restrictions, we cannot rule out that new Turkish migrants living with people born in Germany actually do live together with other German born people of Turkish migration background. However, in models not presented here we found that having people with similar ethnic background among the three closest friends does not affect religiosity.

\section{REFERENCES}

Akresh, I. R.

2011 “Immigrants' religious participation in the United States", Ethnic and Racial Studies 34: 643-661.

Alba, R.

2005 "Bright vs. blurred boundaries: Second-generation assimilation and exclusion in France, Germany, and the United States", Ethnic and Racial Studies, 28: 20-49.

Alba, R., A. J. Raboteau, and J. DeWind (Eds)

2009 Immigration and Religion in America, New York University Press, New York:

Aleksynska, M., and Y. Algan

2010 "Economic and cultural assimilation and integration of immigrants in Europe", CEPII Working Paper 29.

Berry, J.W.

1997 "Immigration, acculturation, and adaptation", Applied Psychology: An International Review, 46: $5-68$.

Bisin, A., T. Verdier, E. Patacchini, and Y. Zenou

2008 "Are Muslim immigrants different in terms of cultural integration?", Journal of the European Economic Association, 6(2-3): 445-456. 
Bommes, M. and M. Krüger-Potratz

2008 Migrationsbericht 2008 Fakten, Analysen, Perspektiven, Campus, Frankfurt am Main and New York: 206

Bramadat, P., and M. Koenig (Eds)

2009 International Migration and the Governance of Religious Diversity, McGill-Queen's University Press: Montreal:

Breton, R.

2012 Different Gods. Integrating Non-Christian Minorities into a Primarily Christian Society, McGillQueen's University Press, Montreal.

1964 "Institutional completeness of ethnic communities and the personal relations of immigrants",

Brubaker, R. American Journal of Sociology, 70: 193-205.

2001 "The return of assimilation?", Ethnic and Racial Studies, 24(4):531-548.

Cadge, W. and E.H. Ecklund

2006 "Religious service attendance among immigrants" American Behavioral Scientist, 49: 1574-1595.

2007 "Immigration and religion", Annual Review of Sociology, 33: 359-379.

Connor, $\mathrm{P}$.

2008 "Increase or decrease? The impact of international migratory event on immigrant religious participation", Journal for the Scientific Study of Religion, 47: 243-257.

2009a "International Migration and Religious Participation: The Mediating Impact of Individual and Contextual Effects", Sociological Forum, 24: 779-803.

2009b "Immigrant religiosity in Canada: multiple trajectories", Journal of International Migration and Integration, 10: 159-175.

2010 "Contexts of immigrant receptivity and immigrant religious outcomes: the case of Muslims in Western Europe", Ethnic and Racial Studies, 33(3): 376-403.

Connor, P., and M. Koenig

2013 "Bridges and Barriers. Religion and Immigrant Occupational Attainment Across Integration Contexts", International Migration Review, 36(1) 3-38.

Diehl, C., and M. Koenig

2009 "Religiosität türkischer Migranten im Generationenverlauf - ein Befund und einige Erklärungsversuche", Zeitschrift für Soziologie 38: 300-319.

Esser, H.

2006 "Does the 'new' immigration require a 'new' theory of intergenerational integration?", International Migration Review, 38: 1126-1159.

Fleischmann, F., and K. Phalet

2012 "Integration and religiosity among the Turkish second generation in Europe: a comparative analysis across four capital cities", Ethnic and Racial Studies, 35(2) 320-341.

Foner, N, and R. Alba

2008 "Immigrant religion in the U.S. and Western Europe: Bridge or Barrier to Inclusion?", International Migration Review 42(2):360-392.

Green, N. L.

2002 "Religion et ethnicité. De la comparaison spatiale et temporelle", Annales, Histoire, Sciences Sociales 57(1): 127-144

Hagan, J., and H. R. Ebaugh

2003 "Calling upon the sacred: migrants' use of religion in the migration process", International Migration Review, 37(4):1145-1162.

Hardin, R.

2001 "Identity: Social", in N. J. Smelser and P. B. Baltes (Eds), International Encyclopedia of the Social and Behavioral Sciences, Elsevier. Oxford: 7166-7170

Hans, S.

2010 Assimilation oder Segregation? VS Verlag für Sozialwissenschaften, Wiesbaden.

Herberg, W.

1956 Protestant, Catholic, Jew. An Essay in American Religious Sociology, Doubleday \& Company, New York. 
Hirschman, C.

2004 "The role of religion in the origins and adaptation of immigrant groups in the United States", International Migration Review, 38: 1206-1233.

Laurence, J.

2012 The Emancipation of Europe's Muslims, Princeton University Press, Princeton.

Levitt, $\mathrm{P}$.

2003 "You know, Abraham really was the first immigrant: religion and transnational migration", International Migration Review, 37(3): 847-873.

Maliepaard, M., M. Lubbers, and M. Gijsberts

2010 "Generational differences in ethnic and religious attachment and their interrelation: A study among Muslim minorities in the Netherlands", Ethnic and Racial Studies, 33: 451-471.

Massey, D. S., and M. E. Higgins

2011 "The effect of immigration on religious belief and practice: A theologizing or alienating experiences", Social Science Research, 40: 1371-1389.

Mitchell, C.

2006 "The Religious Content of Ethnic Identities", Sociology, 40(6):1135-1152.

Mol, $\mathrm{H}$.

1979 "Theory and Data on the Religious Behaviour of Migrants", Social Compass 26(1): 31-39.

Phalet, K., M. Gijsberts, and L. Hagendoorn

2008 "Migration and religion: testing the limits of secularisation among Turkish and Moroccan Muslims in the Netherlands 1998-2005", Kölner Zeitschrift für Soziologie und Sozialpsychologie. Sonderheft, 48: 412-436.

Phalet, K., and U. Schönpflug

2001 "Intergenerational Transmission in Turkish Immigrant Families", Journal of Comparative Family Studies, 32(4): 489-504.

Schiffauer, W.

2009 Nach dem Islamismus, Suhrkamp, Frankfurt am Main.

Smith, T.

1978 "Religion and ethnicity in America", American Historical Review, 83: 1155-1185.

Smits, F., S. Ruiter, and F. van Tubergen

2010 "Religious practices among Islamic immigrants: Moroccans and Turkish men in Belgium", Journal for the Scientific Study of Religion, 49: 247-263.

Stolz, J.

2009 "Explaining Religiosity: Towards a Unified Theoretical Model", British Journal of Political Science, 60: 345-376.

Tezcan, L.

2003 "Das Islamische in den Studien zu Muslimen in Deutschland", Zeitschrift für Soziologie, 32(3): 237-261.

Van Tubergen, F.

2013 "Religious chance of new immigrants in the Netherlands: The event of migration", Social Science Research, 42(3): 715-725.

Van Tubergen, F. and J. I. Sindradottir

2011 "The religiosity of immigrants in Europe: a cross-national study", Journal for the Scientific Study of Religion, 50: 272-288.

Voas, D., and F. Fleischmann

2012 "Islam Moves West: Religious Change in the First and Second Generations", Annual Review of Sociology 38.

Yavuz, M. H.

2003 Islamic Political Identity in Turkey, Oxford University Press: Oxford.

Zolberg, A. R., and L. Litt Woon

1999 "Why Islam Is Like Spanish: Cultural Incorporation in Europe and the United States", Politics \& Society 27(1): 5-38.

Zubrzycki, G.

2006 The Crosses of Auschwitz: Nationalism and Religion in Post-Communist Poland. University of Chicago Press, Chicago. 